\title{
Fibroblast-activation protein: a single marker that confidently differentiates morpheaform/ infiltrative basal cell carcinoma from desmoplastic trichoepithelioma
}

\author{
Ossama Abbas, Joanna E Richards and Meera Mahalingam \\ Dermatopathology Section, Department of Dermatology, Boston University School of Medicine, \\ Boston, MA, USA
}

\begin{abstract}
Microscopically, differentiating desmoplastic trichoepithelioma from morpheaform/infiltrative basal cell carcinoma can be difficult as both show 'islands and strands of basaloid cells embedded in a sclerotic stroma'. A superficial shave biopsy further compounds the diagnostic conundrum. Although a plethora of immunohistochemical markers have been touted as being of use as adjunct histologic tools, none thus far appears to be consistent and reliable in terms of specificity and/or sensitivity. Fibroblast-activation protein, a type II membrane-bound glycoprotein belonging to the serine protease family, is expressed in the granulation tissue of healing wounds. More recently, it has been identified as a marker of reactive tumor stromal fibroblasts, as it is reportedly selectively expressed in peritumoral stromal fibroblasts of multiple epithelial cancers including cutaneous malignancies such as basal cell carcinoma. Given this, we sought to ascertain the use of fibroblast-activation protein in distinguishing morpheaform/infiltrative basal cell carcinoma from desmoplastic trichoepithelioma. Immunohistochemical staining for fibroblast-activation protein was performed on desmoplastic trichoepithelioma $(n=25)$ and morpheaform/infiltrative basal cell carcinoma $(n=25)$, with the control group comprising scars from reexcision specimens $(n=10)$. As expected, fibroblast-activation protein expression was observed in stromal fibroblasts of all control cases $(10$ of $10,100 \%)$. Of interest, fibroblastactivation protein expression was observed in peritumoral fibroblasts of all cases of morpheaform/infiltrative basal cell carcinoma (25 of 25, 100\%) but not in any cases of desmoplastic trichoepithelioma (0 of 25, $0 \%$ ). A gradient of fibroblast-activation protein expression was observed in morpheaform/infiltrative basal cell carcinoma with more intense expression noted in fibroblasts abutting the tumor cells, a less intense expression in the distal peritumoral stromal portion, and minimal to loss of expression in adjacent normal tissue. In summary, findings from this study underscore the use of fibroblast-activation protein as a histologic adjunct in confidently differentiating morpheaform/infiltrative basal cell carcinoma from desmoplastic trichoepithelioma.
\end{abstract}

Modern Pathology (2010) 23, 1535-1543; doi:10.1038/modpathol.2010.142; published online 13 August 2010

Keywords: basal cell carcinoma; desmoplastic trichoepithelioma; fibroblast-activation protein

Morpheaform/infiltrative basal cell carcinoma is an aggressive distinct clinical and histologic variant of basal cell carcinoma that usually presents as a

Correspondence: Professor M Mahalingam, MD, PhD, FRCPath, Dermatopathology Section, Department of Dermatology, Boston University School of Medicine, 609 Albany Street, J-301, Boston, MA 02118, USA.

E-mail: mmahalin@bu.edu

Received 20 May 2010; revised 11 June 2010; accepted 11 June 2010; published online 13 August 2010 solitary, ill-defined, smooth, shiny, flat or slightly depressed, indurated plaque on the face of elderly patients. ${ }^{1-3}$ Histopathology reveals infiltrating strands and islands of basophilic epithelioid cells, typically one or few cells thick, embedded in a dense sclerotic stroma. ${ }^{1-3}$ Unlike other basal cell carcinoma variants, peripheral palisading, stromal mucin, and a clefting artifact are typically not observed. ${ }^{1-3}$

Desmoplastic trichoepithelioma is an uncommon benign neoplasm of follicular derivation that usually manifests as a sporadic asymptomatic small 
indurated annular lesion with a raised border and a depressed center over the face of adolescents and young adults. ${ }^{3-6}$ Like morpheaform/infiltrative basal cell carcinoma, desmoplastic trichoepithelioma is characterized by infiltrating strands and islands of monomorphic, basaloid cells with scant cytoplasm and prominent oval nuclei embedded in a sclerotic and hypocellular stroma. ${ }^{3-6}$ Features of use in distinguishing desmoplastic trichoepithelioma from morpheaform/infiltrative basal cell carcinoma include the additional presence of variably sized horn cysts and foreign-body granulomas in the former. ${ }^{3-6}$

Although desmoplastic trichoepithelioma is a benign tumor that can be managed by conservative treatment such as curettage or shave biopsy, morpheaform/infiltrative basal cell carcinoma is an aggressive malignant neoplasm that requires complete excision usually with Mohs micrographic surgery. ${ }^{1-6}$ Based on the different biologic behaviors, the histopathologic distinction of desmoplastic trichoepithelioma from morpheaform/infiltrative basal cell carcinoma is not just semantics but crucial to patient management. This has thus driven an extensive effort to find an immunohistochemical marker of utility in differentiating the two. Immunohistochemical markers tested to date include $\mathrm{CD} 34,,^{3,7-10}$ bcl-2, ${ }^{3,9-12} \mathrm{CD} 10,{ }^{3,13}$ Ber-EP4, ${ }^{10,14}$ androgen receptor (AR), ${ }^{3,15,16}$ CK20, ${ }^{3,16,17}$ stromelysin- $3,{ }^{18}$ p53, ${ }^{3,19,20} \mathrm{Ki}-67,{ }^{3,19} \mathrm{p} 21,{ }^{19}$ transforming growth factor (TGF)- $\beta,{ }^{21}$ lectins, ${ }^{19,22}$ neurofilaments, ${ }^{23}$ and $\mathrm{p} 75$ neurotrophin receptor. ${ }^{24}$ None of these, to date, appears to be reliable in confidently differentiating desmoplastic trichoepithelioma from morpheaform/ infiltrative basal cell carcinoma (Table 1).

Fibroblast-activation protein (FAP) is a type II membrane-bound glycoprotein that belongs to the serine protease family as it has both a dipeptidyl peptidase and a collagenolytic activity. ${ }^{25,26}$ It has recently been identified as a marker of reactive tumor stromal fibroblasts, as it is selectively expressed in peritumoral stromal fibroblasts of multiple epithelial cancers including breast, colorectal, pancreatic and lung carcinomas, and in the granulation tissue of healing wounds. ${ }^{25-29}$ Similarly, FAP expression has also been shown to be upregulated in the stromal fibroblasts of cutaneous epithelial malignancies such as basal and squamous cell carcinomas as well as benign and malignant melanocytic lesions. ${ }^{30,31}$

In this study, we sought to ascertain the use of expression of FAP in differentiating morpheaform/ infiltrative basal cell carcinomas from desmoplastic trichoepithelioma.

\section{Materials and methods}

The study was approved by the institutional review board of Boston Medical Center (H-29370). Archival materials with a diagnosis of desmoplastic trichoepithelioma and morpheaform/infiltrative basal cell carcinoma were retrieved from the database of the Skin Pathology Laboratory, Boston University School of Medicine, Boston, MA. A total of 25 cases of desmoplastic trichoepithelioma and 25 cases of morpheaform/infiltrative basal cell carcinoma fit criteria for inclusion in the study. The histologic sections of all cases were re-reviewed and the diagnoses were confirmed by the dermatopathologist (MM). Of the 25 cases of desmoplastic trichoepithelioma, 9 were sampled using shave biopsy technique, 14 using punch biopsy, and 2 using excisional biopsy. Of the 25 cases of morpheaform/ infiltrative basal cell carcinoma, 7 were sampled using shave biopsy technique, 13 using punch biopsy, and 5 using excisional biopsy. Only cases with a straightforward histopathologic diagnosis of desmoplastic trichoepithelioma and morpheaform/ infiltrative basal cell carcinoma were included in the study. Clinical information was extracted from the medical records. All patient data were deidentified. Ten scars (ranging from 2 to 12 weeks in age) from re-excision specimens served as controls.

Criteria for diagnosis of desmoplastic trichoepithelioma included a symmetric proliferation of basaloid strands and islands of cells with minimal cytologic atypia, and/or horn cysts. Pertinent negatives were the absence of a connection of the tumoral cells with the epidermis and clefting artifact.

Criteria for diagnosis of morpheaform/infiltrative basal cell carcinoma included an asymmetric proliferation of basaloid strands and islands of cells with cytologic atypia, frequent connection to the overlying epidermis and presence of clefting artifact. Pertinent negatives were the absence of horn cysts and foci of dystrophic calcification.

\section{Immunohistochemical Analysis}

Sections (5- $\mu \mathrm{m}$ thick) were obtained for immunohistochemical studies, which were performed on formalin-fixed, paraffin-embedded tissue. The avidin-biotin complex immunoperoxidase method for FAP was carried out as previously described. ${ }^{27-29}$ In brief, clone D8 (FAP/seprase antibody, 1:200; SUNY, Stony Brook, NY, USA) was applied to sections pretreated with microwave $(10 \mathrm{~min})$ in $0.01 \mathrm{M}$ TrisEDTA buffer ( $\mathrm{pH}$ 9.0). After incubation with the primary antibody, endogenous peroxidase activity was blocked by treating the sections for $5 \mathrm{~min}$ with $3 \%$ hydrogen peroxide in Tris-buffered saline. As the secondary antibody, we used a biotinylated horse anti-rat IgG (1:200; Vector Laboratories, Burlingame, CA, USA). Chromogen 3,30-diaminobencidine was used for the visualization of the final reaction product. Sections were counterstained with Harris' hematoxylin. Appropriate positive and negative controls were included. All stained slides were initially reviewed and scored by the first author (OA) and re-reviewed by the dermatopathologist 
Table 1 Historic overview of different immunohistochemical markers used in differentiating TE from BCC

\begin{tabular}{|c|c|c|c|c|}
\hline Marker & Localization & References & $\begin{array}{l}\text { Entities } \\
\text { (number) }\end{array}$ & Results \\
\hline \multirow{5}{*}{ CD34 } & \multirow{5}{*}{$\begin{array}{l}\text { Peritumoral } \\
\text { stroma }\end{array}$} & 7 & $\begin{array}{l}16 \text { TE, } 19 \text { BCC (10 BCCN, } 6 \text { BCCS, } \\
3 \text { BCC desmoplastic) }\end{array}$ & TE, $100 \%$ positive; BCC, $0 \%$ \\
\hline & & 8 & $10 \mathrm{dTE}, 10 \mathrm{mBCC}$ & dTE, $80 \%$ positive; mBCCs, $30 \%$ \\
\hline & & 9 & $\begin{array}{l}10 \text { TEs, } 15 \text { BCCs ( } 2 \text { early, } 2 \text { BCCN, } \\
7 \text { ulcerative, } 3 \text { morpheic, } 1 \text { BCCI) }\end{array}$ & TE, $20 \%$ positive; $\mathrm{BCC}, 7 \%$ positive \\
\hline & & 10 & & TE, $56 \%$ positive; BCC, $14 \%$ positive \\
\hline & & 3 & dTE (19), mBCC (18) & dTE, $0 \%$ positive; mBCC, $0 \%$ positive \\
\hline \multirow{5}{*}{$b c l-2$} & \multirow{5}{*}{ Lesional cells } & 11 & $\mathrm{TE}(10), \mathrm{BCC}(10)^{\mathrm{a}}$ & $\begin{array}{l}\text { TE, } 100 \% \text { positive (peripheral tumoral staining } \\
\text { only); BCC, } 100 \% \text { positive (diffuse tumoral staining) }\end{array}$ \\
\hline & & 12 & TE (10), BCC (nodular) (20) & $\begin{array}{l}\text { TE, } 100 \% \text { positive (peripheral tumoral staining } \\
\text { only); BCC, } 95 \% \text { positive (diffuse tumoral staining) }\end{array}$ \\
\hline & & 9 & $\begin{array}{l}10 \text { TEs, } 15 \text { BCCs ( } 2 \text { early, } 2 \text { BCCN, } \\
7 \text { ulcerative, } 3 \text { morpheic, } 1 \text { BCCI) }\end{array}$ & $\begin{array}{l}\text { TE, } 50 \% \text { positive ( } 20 \% \text { peripheral tumoral staining, } \\
30 \% \text { diffuse tumoral staining); BCC, } 47 \% \text { positive } \\
\text { ( } 40 \% \text { diffuse tumoral staining, } 7 \% \text { peripheral } \\
\text { tumoral staining) }\end{array}$ \\
\hline & & 10 & $\begin{array}{l}\text { TE (36, including } 7 \text { dTEs), } \\
\text { BCC ( } 43 \text {, including } 7 \text { miBCCs) }\end{array}$ & $\begin{array}{l}\text { TE, } 27 \% \text { positive (diffuse tumoral staining); BCC, } \\
9 \% \text { positive (peripheral tumoral staining) }\end{array}$ \\
\hline & & 3 & $19 \operatorname{dTE}(19)$, mBCC (18) & dTE, $100 \%$ positive; mBCC, $100 \%$ positive \\
\hline \multirow[t]{2}{*}{ CD10 } & \multirow[t]{2}{*}{$\begin{array}{l}\text { Lesional cells } \\
\text { and peritumoral } \\
\text { stroma }\end{array}$} & 13 & TE (13), nodular BCC (23) & $\begin{array}{l}\text { TE, } 92 \% \text { positive (peritumoral stroma and tumor } \\
\text { cells in } 2 \text { and only stroma in 10); BCC, } 87 \% \text { positive } \\
\text { (only tumor cell positivity in 17, tumor cells and } \\
\text { stroma in } 3 \text { ) }\end{array}$ \\
\hline & & 3 & 19 dTE (19), mBCC (18) & $\begin{array}{l}\text { dTE, inconsistent stromal positivity } \\
\text { mBCC, } 44 \% \text { (stroma in } 8 \text { and tumor aggregates in } 7 \text { ) }\end{array}$ \\
\hline
\end{tabular}

\begin{tabular}{|c|c|c|c|c|}
\hline Ber-EP4 & Lesional cells & 14 & $\begin{array}{l}\text { TE ( } 36 \text { including } 7 \text { dTEs), } \\
\text { BCC ( } 43 \text { including } 7 \text { miBCCs) } \\
\text { dTE (16), miBCC (28) }\end{array}$ & $\begin{array}{l}\text { TE, } 81 \% \text { positive (including } 71 \% \text { of dTEs); BCC, } \\
100 \% \text { positive } \\
\text { dTE, } 75 \% \text { positive; BCC, } 100 \% \text { positive }\end{array}$ \\
\hline $\begin{array}{l}\text { Androgen } \\
\text { receptor }\end{array}$ & $\begin{array}{l}\text { Nuclei of } \\
\text { lesional cells }\end{array}$ & $\begin{array}{l}15 \\
3\end{array}$ & $\begin{array}{l}\text { TE (6), miBCC }{ }^{a}(32) \\
19 \text { dTE (19), mBCC (18) } \\
\text { dTE (15), mBCC (31) }\end{array}$ & $\begin{array}{l}\text { TE, } 0 \% \text { positive; BCC, } 78 \% \text { positive } \\
\text { dTE, } 0 \% \text { positive; mBCC, } 100 \% \\
\text { dTE, } 13 \% \text { positive; mBCC, } 65 \% \text { positive }\end{array}$ \\
\hline CK20 & $\begin{array}{l}\text { Merkel cells in } \\
\text { the epithelial } \\
\text { strands }\end{array}$ & $\begin{array}{l}16 \\
3\end{array}$ & $\begin{array}{l}\text { dTE (15), mBCC (31) } \\
\text { dTE (19), mBCC (18) } \\
\text { dTE (14), mBCC (11) }\end{array}$ & $\begin{array}{l}\text { dTE, } 100 \% \text { positive; mBCC, } 3 \% \text { positive } \\
\text { dTE, } 100 \% \text { positive; mBCC, } 0 \% \\
\text { dTE, } 100 \% \text { positive; mBCC, } 9 \% \text { positive }\end{array}$ \\
\hline Stromelysin & $\begin{array}{l}\text { Peritumoral } \\
\text { stroma }\end{array}$ & 18 & dTE (12), mBCC (50) & dTE, $0 \%$ positive; mBCC, $68 \%$ positive \\
\hline p53 & Lesional cells & $\begin{array}{l}19 \\
20\end{array}$ & $\begin{array}{l}\text { TE }(16), \text { BCC }^{\text {a }}(20) \\
20 \text { TEs, } 20 \text { BCCs (16 solid type, } \\
3 \text { with adenoid features, } 1 \text { BCCS) } \\
\text { dTE (19), mBCC (18) }\end{array}$ & $\begin{array}{l}\text { Overexpression in BCC compared to TE } \\
\text { No statistically significant differences between cell } \\
\text { indices (\% of positive cases not specified) } \\
\text { Both entities-Positive in at least few cells in all } \\
\text { cases, a thirds of mBCCs showed no difference in } \\
\text { expression compared to dTE }\end{array}$ \\
\hline Ki-67 & Lesional cells & 19 & $\begin{array}{l}\text { TE (16), } \text { BCC }^{\mathrm{a}}(20) \mathrm{s} \\
\text { dTE (19), mBCC (18) }\end{array}$ & $\begin{array}{l}\text { BCC, qualitatively greater proliferative fraction than } \\
\text { TE } \\
\text { Both entities-Positive in at least few cells in all } \\
\text { cases, a thirds of mBCCs showed no difference in } \\
\text { expression compared to dTE }\end{array}$ \\
\hline $\mathrm{p} 21$ & Lesional cells & 19 & TE (16), BCC ${ }^{\mathrm{a}}(20)$ & BCC, $10 \%$ scattered nuclear positivity; TE, negative \\
\hline TGF- $\beta$ & Lesional cells & 21 & TE (5), BCC ?subtype(5) & TE, $100 \%$ positive; BCC, $20 \%$ positive \\
\hline
\end{tabular}


Table 1 Continued

\begin{tabular}{llll}
\hline Marker & Localization & References & $\begin{array}{l}\text { Entities } \\
\text { (number) }\end{array}$ \\
\hline Lectins & $\begin{array}{l}\text { Peritumoral } \\
\text { stroma }\end{array}$ & 22 & 103 BCCs (55 nonulcerated, \\
& & $\begin{array}{l}48 \text { ulcerated) } \\
10 \text { TEs, 15 BCCs (2 early, 2 BCCN, } \\
7 \text { Ulcerative, } 3 \text { morpheic, 1 BCCI) }\end{array}$
\end{tabular}

Results

$96 \%$, bandlike peritumorous staining

TE, $90 \%$ positive $(10 \%$ positive continuous bandlike peritumorous staining, $80 \%$ discontinuous bandlike); BCC, $60 \%$ positive ( $40 \%$ positive continuous bandlike peritumorous staining, $20 \%$ discontinuous bandlike)

\begin{tabular}{lllll}
\hline $\begin{array}{l}\text { Neuro- } \\
\text { filaments }\end{array}$ & $\begin{array}{l}\text { Perifollicular } \\
\text { nerve plexus }\end{array}$ & ${ }^{23}$ & $\begin{array}{l}\text { 5 TEs, 10 BCCs (7 solid, } \\
\text { 2 infiltrative, 1 morpheaform) }\end{array}$ & TE, 100\% positive; BCC, 100\% positive \\
\hline p75NTR & Lesional cells & ${ }^{24}$ & 16 dTE (16), mBCC (14) & dTE, 100\% positive in 100\%; BCC, 14\% positive \\
\hline FAP & Stroma & This study & dTE (25), miBCC (25) & dTE, 0\%; miBCC, 100\% (gradient observed) \\
\hline
\end{tabular}

BCC, basal cell carcinoma; CK20, cytokeratin 20; dTE, desmoplastic trichoepithelioma; miBCC, morpheaform or infiltrative basal cell carcinoma; mBCC, morpheaform basal cell carcinoma; p75NTR, p75 neurotrophin receptor; TE, trichoepithelioma; TGF- $\beta$, transforming growth factor- $\beta$; FAP, fibroblast-activation protein.

${ }^{a}$ Subtype of BCC not specified.

(MM) in a masked manner to ensure consistency of interpretation. Stained sections were scored as positive or negative.

\section{Statistical Analysis}

The statistical association of FAP expression was analyzed using the Fisher's exact test to determine whether there were differences of significance in expression between the two entities. A two-tailed $P$-value of $<0.05$ was considered to be statistically significant.

\section{Results}

The clinical features of this series of desmoplastic trichoepithelioma and morpheaform/infiltrative basal cell carcinoma are outlined in Table 2. Positive FAP staining was noted by ascertaining cytoplasmic expression of stromal fibroblasts. Any nuclear staining was considered background artifact. All control cases of scar showed positive expression of FAP within fibroblasts (Figure 1). Positive staining of mature sebocytes within sebaceous glands was also noted in a few cases.

\section{Desmoplastic Trichoepithelioma}

Patients with desmoplastic trichoepithelioma (19 females and 6 males) ranged in age from 14 to 77 years (mean of 45 years). All lesions were located on the face except for one case on the back.

All 25 cases of desmoplastic trichoepithelioma showed negative expression of FAP (Figure 2).
Table 2 Demographic data of patients in study

\begin{tabular}{lcc}
\hline & $d T E$ & miBCC \\
\hline Mean age (years, range) & $45(14-77)$ & $72(42-85)$ \\
Sex (male/female ratio) & $6 / 19$ & $15 / 10$ \\
Location (\%) & Face (96) & Head (60) \\
& Back (4) & Trunk (20) \\
& & Extremities (20)
\end{tabular}

DTE, desmoplastic trichoepithelioma; miBCC, morpheaform/infiltrative basal cell carcinoma.

\section{Morpheaform/Infiltrative Basal Cell Carcinoma}

Patients were with morpheaform/infiltrative basal cell carcinoma ( 15 men, 10 women) aged from 42 to 85 years (mean, 72 years). Lesions were located on the head in $15(60 \%)$ cases, trunk in $5(20 \%)$ cases, and extremities in $5(20 \%)$.

Fibroblast-activating protein was expressed in peritumoral stromal fibroblasts of all 25 cases of morpheaform/infiltrative basal cell carcinoma $(100 \%)$ (Figure 2). An inverse gradient was observed in FAP expression with more intense expression noted in fibroblasts abutting tumor cells with the intensity of staining of stromal fibroblasts decreasing with increasing distance from the tumor.

The difference in FAP expression between morpheaform/infiltrative basal cell carcinoma and desmoplastic trichoepithelioma was statistically significant $(P=0.000003)$.

\section{Discussion}

Although mutations in oncogenes or tumor suppressor genes contribute to the mechanisms initiating 
a
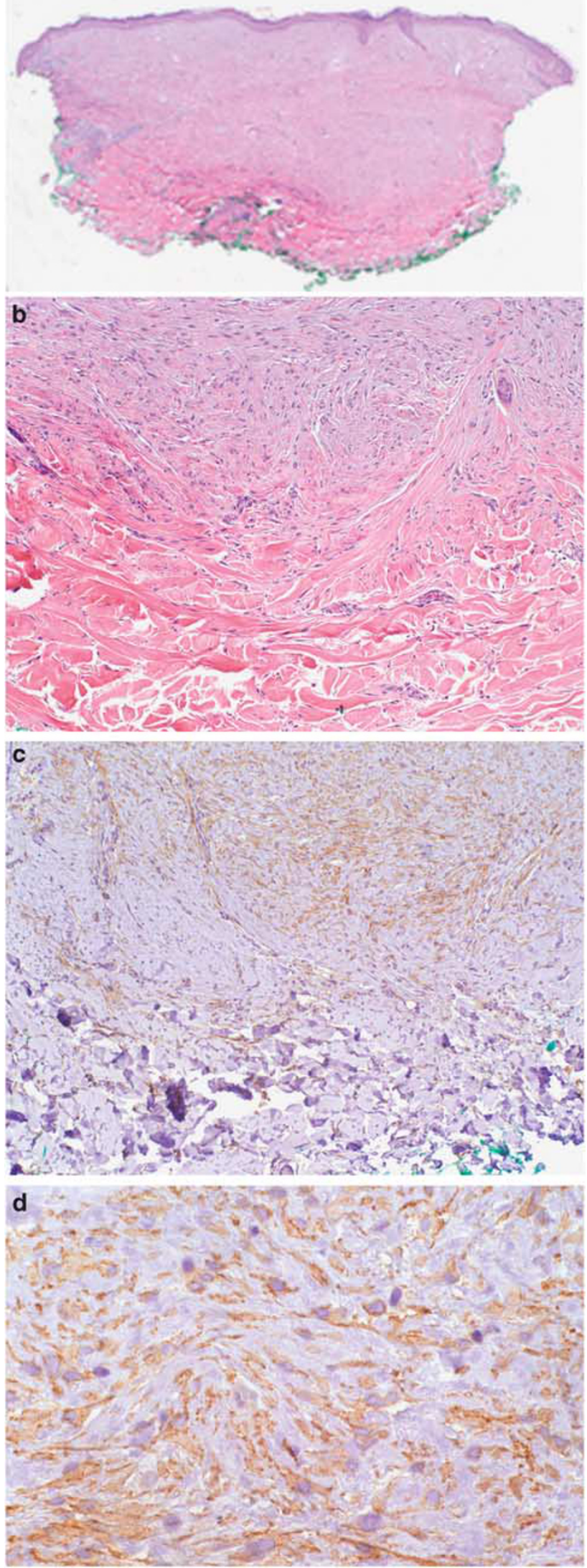

cancer development, progression of cancer is the result of complex reciprocal interactions between neoplastic cells and their microenvironment. ${ }^{32-35}$ The stroma appears to be important at different steps of tumor progression impacting proliferation, migration, and vascularization of tumor cells as well as degradation of the extracellular matrix (ECM). ${ }^{36,37}$ One stromal component in particular, ie, the activated stromal fibroblast, a fibroblastic cell with a myofibroblastic phenotype, seems to be pivotal to formation of the stroma of cancerous cells. ${ }^{32,36-38}$ Recent studies on a variety of human tumors such as skin, lung, breast, and colon cancers have shown that one of the major functions of these myofibroblasts, similar to that of neoplastic cells, is degradation of the ECM by the production of ECM-degrading enzymes. ${ }^{32,36-38}$ In addition to their expression of $\alpha$-smooth muscle actin, these myofibroblasts also express FAP. ${ }^{25-30,38,39}$ In skin, FAP expression has been shown in stromal fibroblasts of both benign and malignant melanocytic tumors as well as epithelial cancers such as squamous and basal cell carcinomas. $^{30,31}$ The expression pattern in the latter category was noted as a gradient. ${ }^{30}$ Findings from this study corroborate this in that all cases $(100 \%)$ of morpheaform/infiltrative basal cell carcinomas showed strong FAP staining of peritumoral stromal fibroblasts. Like Huber et $a l^{30}$ we observed a gradient in the pattern of FAP staining with prominent expression noted in fibroblasts directly surrounding the tumor cells, a more diffuse pattern in the distal part of the peritumoral stroma and with minimal or absent expression in adjacent normal tissue.

None of the cases of desmoplastic trichoepithelioma showed FAP expression in stromal fibroblasts, making this a specific and sensitive immunohistochemical marker and more importantly one that reliably distinguishes morpheaform/infiltrative basal cell carcinoma from desmoplastic trichoepithelioma. Immunohistochemical markers putatively useful in reliably differentiating trichoepithelioma (and/or trichoblastoma) and basal cell carcinoma in general and desmoplastic trichoepithelioma and morpheaform/infiltrative basal cell carcinoma in particular include CD34, Bcl-2, CK20, and AR. ${ }^{3,7-12,15-17}$ Positive peritumoral staining of trichoepithelioma and desmoplastic trichoepithelioma by CD34, shown by Kirchmann et al, in $100 \%$ of cases of both with negative staining in all cases of basal cell carcinoma was contradicted by subsequent studies that showed

Figure 1 Representative example of scar from study. (a and b) H\&E: (a) original magnification, $\times 2$ ); (b) original magnification, $\times 10$ (scar tissue in upper half and normal connective tissue in lower half). (c and d) Immunohistochemical staining for FAP: (c) (original magnification, $\times 10$ ); positive FAP expression in stromal fibroblasts in scar tissue and lack of expression in normal connective tissue; (d) original magnification, $\times 20$. 

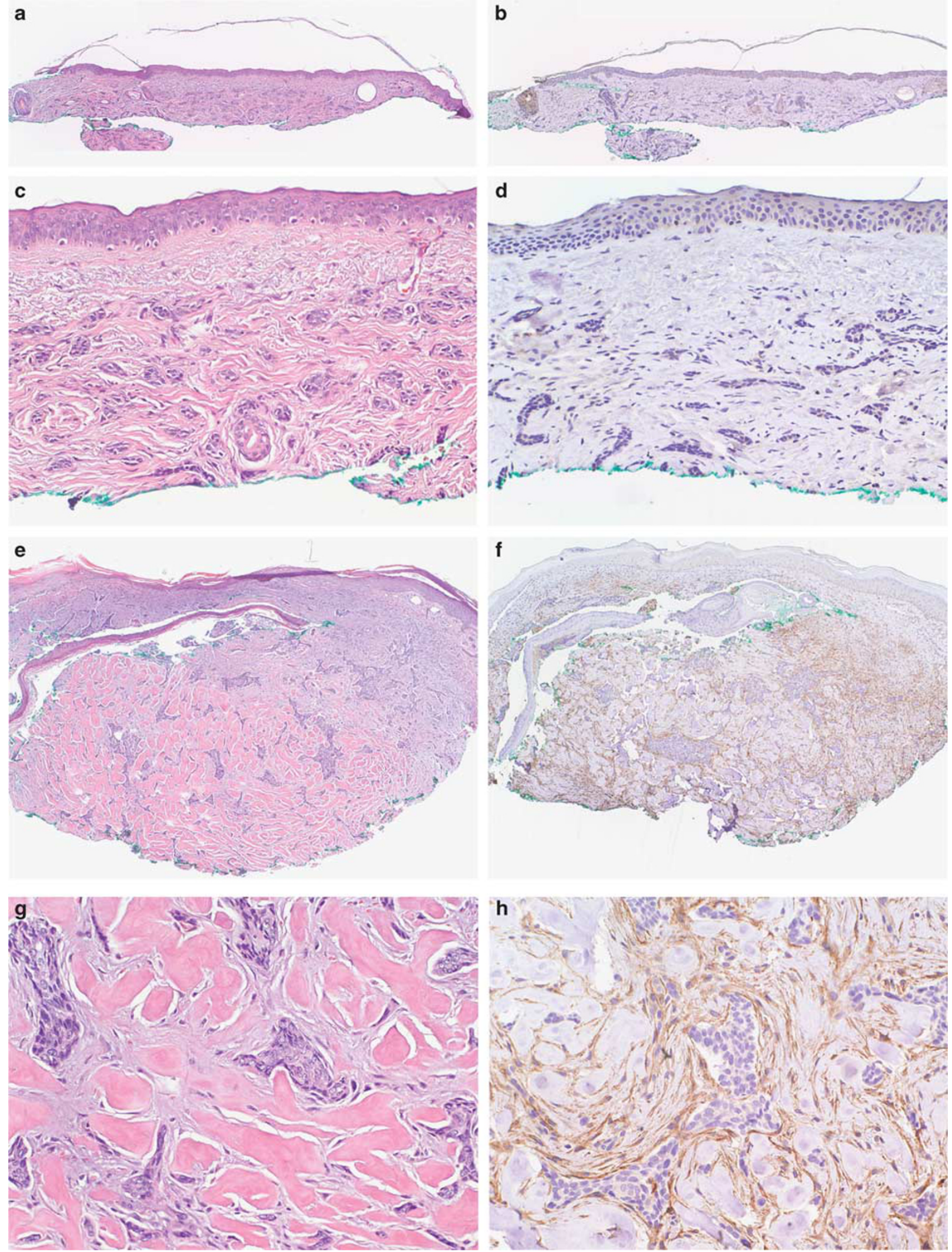

Figure 2 Representative examples of desmoplastic trichoepithelioma and morpheaform/infiltrative basal cell carcinoma from study (a-d) Desmoplastic trichoepithelioma; (e-h) BCC, morpheaform, keloidal type; H\&E: (a, e) original magnification, $\times 4$; (c, g) original magnification, $\times 20$; FAP: $(\mathbf{b}, \mathbf{f})$ original magnification, $\times 4$; $(\mathbf{d}, \mathbf{h})$ original magnification, $\times 20$. 
positive peritumoral staining in some cases of basal cell carcinoma and absence of the same in cases of trichoepithelioma. ${ }^{7-10}$ The diffuse staining of bcl-2 in tumor nests of basal cell carcinoma and peripheral staining of tumor nests in cases of trichoepithelioma reported in some studies was refuted by others claiming that the differential expression pattern at the periphery compared with the center of lesional aggregates cannot be assessed reliably, as the epithelial strands are usually thin in the desmoplastic variants of both neoplasms. ${ }^{3,9-12}$ Use of expression of the AR, initially shown by Izikson et al, were later reproduced by Costache et al. ${ }^{3}$ Both groups showed AR expression in $>75 \%$ of basal cell carcinomas tested and lack of the same in both trichoepithelioma and desmoplastic trichoepithelioma. ${ }^{15}$ Undermining these results were those obtained by Katona et al who found AR expression in only $65 \%$ of basal cell carcinomas tested and also showed AR positivity in $13 \%$ of desmoplastic trichoepitheliomas in their series. ${ }^{16}$ Several studies have shown that cytokeratin 20-positive cells, labeling Merkel cells, are present in only trichoepitheliomas, including desmoplastic trichoepithelioma, but not in basal cell carcinomas, including morpheaform basal cell carcinoma. ${ }^{3,17}$ Conflicting this is evidence showing the presence of CK20-positive cells in a few cases of morpheaform basal cell carcinoma. ${ }^{17}$ In addition, small and superficial biopsy specimens resulting in falsely negative results question the discriminatory values of this marker.

Desmoplasia, a paucicellular host response characterized by a hyalinized or sclerotic stroma, has classically been associated with the malignant phenotype of neoplasias of noncutaneous origins including breast, prostate, oral squamous cell, pancreatic, and thyroid carcinomas, among others. ${ }^{40-44}$ In contrast, in the skin, the desmoplastic stromal response may be observed in malignant and benign tumors. ${ }^{3,4,45-52}$ Given this, the obvious question is whether desmoplasia associated with a benign neoplasm is any different from that associated with malignant tumors. Findings from this study indicate that there does appear to be a difference in mechanisms underlying the desmoplastic reaction pattern in a malignant cutaneous epithelial neoplasm compared with one that is benign. Does the stromal response actually contribute to the biologic behavior of the neoplasm or is it a mere epiphenomenon? That desmoplasia in cutaneous malignancies such as squamous cell, sebaceous, and sweat gland carcinomas is associated with a poorer prognosis with a higher risk of tumor recurrence, metastasis, and/or tumor-related death, argues in favor of the former hypothesis. ${ }^{50,51}$ A scientific explanation for this might be that collagen production is induced by tumor cells that cause activation of fibroblasts and subsequent proliferation..$^{30,39,44,51}$

Expression of FAP has also been previously noted in the granulation tissue of healing wounds. ${ }^{53-55}$ Our findings confirm this in that all scars in this study expressed FAP. The retention of FAP expression in scars provides support for the long-standing hypothesis that cancers may essentially represent nonhealing wounds, ${ }^{53-55}$ as all the scars in our study showed positive staining of stromal fibroblasts similar to morpheaform/infiltrative basal cell carcinoma cases. Multiple cellular and molecular studies have verified this hypothesis by showing that tumors, especially carcinomas, activate the latent wound-healing host program in a prolonged and exaggerated manner. ${ }^{53-55}$ In addition, most of the genes that control the wound-healing process are also important regulators of cancer growth and progression. ${ }^{53-55}$

In conclusion, this study supports the use of FAP as a sole immunohistochemical marker to differentiate morpheaform/infiltrative basal cell carcinoma from desmoplastic trichoepithelioma. Expression of FAP by peritumoral stromal fibroblasts establishes a diagnosis of morpheaform/infiltrative basal cell carcinoma whereas lack of FAP staining supports a diagnosis of desmoplastic trichoepithelioma.

\section{Disclosure/conflict of interest}

The authors declare no conflict of interest.

\section{References}

1 Litzow TJ, Perry HO, Soderstrom CW. Morpheaform basal cell carcinoma. Am J Surg 1968;116:499-505.

2 Carra RA, Taibjeeb SM, Sanders DSA. Basaloid skin tumours: basal cell carcinoma. Curr Diagn Pathol 2007;13:252-272.

3 Costache M, Bresch M, Böer A. Desmoplastic trichoepithelioma versus morphoeic basal cell carcinoma: a critical reappraisal of histomorphological and immunohistochemical criteria for differentiation. Histopathology 2008;52:865-876.

4 Brownstein MH, Shapiro L. Desmoplastic trichoepithelioma. Cancer 1977;40:2979-2986.

5 Dervan PA, O’Hegarty M, O’Loughlin S, et al. Solitary familial desmoplastic trichoepithelioma. A study by conventional and electron microscopy. Am J Dermatopathol 1985;7:277-282.

6 Mamelak AJ, Goldberg LH, Katz TM, et al. Desmoplastic trichoepithelioma. J Am Acad Dermatol 2010; 62:102-106.

7 Kirchmann TT, Prieto VG, Smoller BR. CD34 staining pattern distinguishes basal cell carcinoma from trichoepithelioma. Arch Dermatol 1994;130:589-592.

8 Kirchmann TT, Prieto VG, Smoller BR. Use of CD34 in assessing the relationship between stroma and tumor in desmoplastic keratinocytic neoplasms. J Cutan Pathol 1995;22:422-426.

9 Basarab T, Orchard G, Russell-Jones R. The use of immunostaining for bcl-2 and CD34 and the lectin peanut agglutinin in differentiating between basal cell carcinomas and trichoepitheliomas. Am J Dermatopathol 1998;20:448-452. 
10 Swanson PE, Fitzpatrick MM, Ritter JH, et al. Immunohistologic differential diagnosis of basal cell carcinoma, squamous cell carcinoma, and trichoepithelioma in small cutaneous biopsy specimens. J Cutan Pathol 1998;25:153-159.

11 Smoller BR, Van de Rijn M, Lebrun D, et al. bcl-2 expression reliably distinguishes trichoepitheliomas from basal cell carcinomas. Br J Dermatol 1994;131: 28-31.

12 Poniecka AW, Alexis JB. An immunohistochemical study of basal cell carcinoma and trichoepithelioma. Am J Dermatopathol 1999;21:332-336.

13 Pham TT, Selim MA, Burchette Jr JL, et al. CD10 expression in trichoepithelioma and basal cell carcinoma. J Cutan Pathol 2006;33:123-128.

14 Krahl D, Sellheyer K. Monoclonal antibody Ber-EP4 reliably discriminates between microcystic adnexal carcinoma and basal cell carcinoma. J Cutan Pathol 2007;34:782-787.

15 Izikson L, Bhan A, Zembowicz A. Androgen receptor expression helps to differentiate basal cell carcinoma from benign trichoblastic tumors. Am J Dermatopathol 2005;27:91-95.

16 Abesamis-Cubillan E, El-Shabrawi-Caelen L, LeBoit PE. Merked cells and sclerosing epithelial neoplasms. Am J Dermatopathol 2000;22:311-315.

17 Katona TM, Perkins SM, Billings SD. Does the panel of cytokeratin 20 and androgen receptor antibodies differentiate desmoplastic trichoepithelioma from morpheaform/infiltrative basal cell carcinoma? J Cutan Pathol 2008;35:174-179.

18 Thewes M, Worret WI, Engst R, et al. Stromelysin-3: a potent marker for histopathologic differentiation between desmoplastic trichoepithelioma and morphealike basal cell carcinoma. Am J Dermatopathol 1998; 20:140-142.

19 Lum CA, Binder SW. Proliferative characterization of basal-cell carcinoma and trichoepithelioma in small biopsy specimens. J Cutan Pathol 2004;31:550-554.

20 Abdelsayed RA, Guijarro-Rojas M, Ibrahim NA, et al. Immunohistochemical evaluation of basal cell carcinoma and trichoepithelioma using Bcl-2, Ki67, PCNA and P53. J Cutan Pathol 2000;27:169-175.

21 Verhaegh ME, Arends JW, Majoie IM, et al. Transforming growth factor-beta and bcl-2 distribution patterns distinguish trichoepithelioma from basal cell carcinoma. Dermatol Surg 1997;23:695-700.

22 Vigneswaran N, Haneke E, Peters KP. Peanut agglutinin immunohistochemistry of basal cell carcinoma. J Cutan Pathol 1987;14:147-153.

23 Fernandez-Flores A. Advanced differentiation in trichoepithelioma and basal cell carcinoma investigated by immunohistochemistry against neurofilaments. Folia Histochem Cytobiol 2009;47:61-64.

24 Krahl D, Sellheyer K. p75 Neurotrophin receptor differentiates between morphoeic basal cell carcinoma and desmoplastic trichoepithelioma: insights into the histogenesis of adnexal tumours based on embryology and hair follicle biology. Br J Dermatol 2010;163:138-145.

25 Garin-Chesa P, Old LJ, Rettig WJ. Cell surface glycoprotein of reactive stromal fibroblasts as a potential antibody target in human epithelial cancers. Proc Natl Acad Sci USA 1990;87:7235-7239.

26 Park JE, Lenter MC, Zimmermann RN, et al. Fibroblast activation protein, a dual specificity serine protease expressed in reactive human tumor stromal fibroblasts. J Biol Chem 1999;274:36505-36512.
27 Ariga N, Sato E, Ohuchi N, et al. Stromal expression of fibroblast activation protein/seprase, a cell membrane serine proteinase and gelatinase, is associated with longer survival in patients with invasive ductal carcinoma of breast. Int J Cancer 2001;95:67-72.

28 Cohen SJ, Alpaugh RK, Palazzo I, et al. Fibroblast activation protein and its relationship to clinical outcome in pancreatic adenocarcinoma. Pancreas 2008;37:154-158.

29 Henry LR, Lee HO, Lee JS, et al. Clinical implications of fibroblast activation protein in patients with colon cancer. Clin Cancer Res 2007;13:1736-1741.

30 Huber MA, Kraut N, Schweifer N, et al. Expression of stromal cell markers in distinct compartments of human skin cancers. J Cutan Pathol 2006;33: 145-155.

31 Huber MA, Kraut N, Park JE, et al. Fibroblast activation protein: differential expression and serine protease activity in reactive stromal fibroblasts of melanocytic skin tumors. J Invest Dermatol 2003;120:182-188.

32 Park CC, Bissell MJ, Barcellos-Hoff MH. The influence of the microenvironment on the malignant phenotype. Mol Med Today 2000;6:324-329.

33 Liotta LA, Kohn EC. The microenvironment of the tumour-host interface. Nature 2001;411:375-379.

34 Mueller MM, Fusenig NE. Tumor-stroma interactions directing phenotype and progression of epithelial skin tumor cells. Differentiation 2002;70:486-497.

35 Ruiter D, Bogenrieder T, Elder D, et al. Melanomastroma interactions: structural and functional aspects. Lancet Oncol 2002;3:35-43.

36 Mueller MM, Fusenig NE. Friends or foes-bipolar effects of the tumour stroma in cancer. Nat Rev Cancer 2004;4:839-849.

37 Geiger TR, Peeper DS. Metastasis mechanisms. Biochim Biophys Acta 2009;1796:293-308.

38 Kalluri R, Zeisberg M. Fibroblasts in cancer. Nat Rev Cancer 2006;6:392-401.

39 Dolznig H, Schweifer N, Puri C, et al. Characterization of cancer stroma markers: in silico analysis of an mRNA expression database for fibroblast activation protein and endosialin. Cancer Immun 2005;5:10.

40 Iacobuzio-Donahue CA, Argani P, Hempen PM, et al. The desmoplastic response to infiltrating breast carcinoma: gene expression at the site of primary invasion and implications for comparisons between tumor types. Cancer Res 2002;62:5351-5357.

41 Iacobuzio-Donahue CA, Ryu B, Hruban RH, et al. Exploring the host desmoplastic response to pancreatic carcinoma: gene expression of stromal and neoplastic cells at the site of primary invasion. Am J Pathol 2002;160:91-99.

42 Tuxhorn JA, Ayala GE, Smith MJ, et al. Reactive stroma in human prostate cancer: induction of myofibroblast phenotype and extracellular matrix remodeling. Clin Cancer Res 2002;8:2912-2923.

43 Kawashiri S, Tanaka A, Noguchi N, et al. Significance of stromal desmoplasia and myofibroblast appearance at the invasive front in squamous cell carcinoma of the oral cavity. Head Neck 2009;31:1346-1353.

44 Koperek O, Scheuba C, Puri C, et al. Molecular characterization of the desmoplastic tumor stroma in medullary thyroid carcinoma. Int J Oncol 2007;31: 59-67.

45 Ferrara G, Brasiello M, Annese P, et al. Desmoplastic nevus: clinicopathologic keynotes. Am J Dermatopathol 2009;31:718-722. 
46 Michal M, Kerekes Z, Kinkor Z, et al. Desmoplastic cellular blue nevus. Am J Dermatopathol 1995;17: 230-235.

47 Hunt SJ, Kilzer B, Santa Cruz DJ. Desmoplastic trichilemmoma: histologic variant resembling invasive carcinoma. J Cutan Pathol 1990;17:45-52.

48 Abbas O, Mahalingam M. Tumor of the follicular infundibulum: an epidermal reaction pattern? Am J Dermatopathol 2009;31:626-633.

49 Zedek DC, White WL, McCalmont TH. Desmoplastic cellular neurothekeoma: clinicopathological analysis of twelve cases. J Cutan Pathol 2009;36:1185-1190.

50 Brantsch KD, Meisner C, Schönfisch B, et al. Analysis of risk factors determining prognosis of cutaneous squamous-cell carcinoma: a prospective study. Lancet Oncol 2008;9:713-720.
51 Hasebe T, Mukai K, Ishihara K, et al. Sebaceous gland and sweat gland carcinomas of the skin. Clinicopathological study and significance of c-erbB-2 oncoprotein expression. Acta Pathol Jpn 1992;42:585-594.

52 de Almeida LS, Requena L, Rütten A, et al. Desmoplastic malignant melanoma: a clinicopathologic analysis of 113 cases. Am J Dermatopathol 2008;30:207-215.

53 Dvorak HF. Tumors: wounds that do not heal. Similarities between tumor stroma generation and wound healing. N Engl J Med 1986;315:1650-1659.

54 Barr LC, Carter RL, Davies AJ. Encapsulation of tumours as a modified wound healing response. Lancet 1988;2:135-137.

55 Schafer M, Werner S. Cancer as an overhealing wound: an old hypothesis revisited. Nat Rev Mol Cell Biol 2008;9:628-638. 